\title{
Comparative Phylogenetic Study of Four Genes of Mitochondrial Genome in Tenpounder Fishes (Order: Elopiformes)
}

\author{
Vellaichamy RAMANADEVI, Muthusamy THANGARAJ* \\ Annamalai University, Centre of Advanced Study in Marine Biology, 608502 Parangipettai, \\ Tamil Nadu, India; coralholder@yahoo.com (*corresponding author)
}

\begin{abstract}
The Elopiformes represent a group of seven known species of fishes found in marine and estuarine ecosystem and many of them are endemic to East Asia. To date published morphological and molecular phylogenetic hypothesis of Tenpounder fishes are part congruent and there are some areas of significant disagreement with respect to species relationships. The present study analyzed the sequence data from four genes (Cytb, CO1, 16S and 12S rRNA) of mitochondrial genome for the attempt to estimate the relationships among five species such as Elops saurus, E. affinis, E. smithi, E. machnata and E. hawaiensis and to assess the phylogenetic utility of these markers. The Kimura 2- parameter (K2P) genetic distance, average nucleotide frequencies, nucleotide substitution patterns and phylogenetic trees were reconstructed using neighbour joining $(\mathrm{NJ})$ method. The interspecies K2P genetic distance was 0.0158 and intraspecies distance was 0.0042 based on the barcoding gene, CO1 sequence data. Whereas the interspecies K2P genetic distance was 0.6140 and intraspecies genetic distance was 0.0020 based on the Cytb data. The four mitochondrial marker genes used in this study showed different type of cluster and we could not confirm the relationship between the five Elops species. This is due to the independent mutation rate of each mtDNA genes. However, this problem can be overcome by analysing in parallel other gene markers.
\end{abstract}

Keywords: Elops, genetic distance, mtDNA genes, phylogeny, Tenpounders

\section{Introduction}

The ladyfishes or tenpounders (genus Elops) are widely distributed in tropical-subtropical, marine and coastal waters (Mcbride et al., 2010). Six species of Elops are recognized worldwide (Eschmeyer and Fong, 2008), but the taxonomy of the group is poorly known and some authors recognize fewer species (Nelson, 2006). Taxonomic uncertainty of Elops is exemplified by the ladyfish, E. saurus, currently recognized as the only species of Elops in the western Atlantic Ocean (Mcbride et al., 2010). Smith (1989) also noted that E. saurus and E. smithi had largely allopatric distributions. Recent work has failed to support the phenotypic hypothesis for this two species (Mcbride et al., 2010). Mcbride et al. (2010) examined specimens of E. saurus and Elops sp. using common morphological, meristic characters and Cytb data that have been used to distinguish six species of Elops worldwide (E. saurus, $E$. affinis, E. lacerta, E. senegalensis, E. machnata and E. hawaiensis). Many taxonomic studies of Elops examined less than 20 specimens per species and for some species even single specimen also used. Hence, there may be even more species of Elops awaiting discovery (Mcbride et al., 2010). Phylogenetically, Obermiller and Pfeiler (2003) identify E. saurus and E. smithi based on $12 S$ and $16 S$ rRNA gene sequence. So far E. senegalensis and E. lacerta are not yet entered into the GenBank database and there is no phylo- genetic analysis work has been made using molecular tools. Based on the study of Mcbride et al. (2010) E. saurus and E. smithi showed ecological specialization in tropical and subtropical habitats may be a foundation for speciation.

Recently three independent research groups have published results from molecular phylogenetic studies of the elopomorphs using mitochondrial ribosomal DNA sequences (Filleul and Lavoue, 2001; Obermiller and Pfeiler, 2003; Wang et al., 2003). Wang et al. (2003) analyzed the elopomorph interrelationships based on the complete $12 S$ rRNA gene sequences (1073 bp) from 42 teleosts including the Elopomorpha (34 spp.). Forey et al. (1996) employed a total-evidence approach in analyzing elopomorph relationships, combining partial nucleotide sequences of the mitochondrial 12S rRNA (345 bp), $16 \mathrm{~S}$ rRNA ( $535 \mathrm{bp}$ ), and nuclear 18S rRNA (1870 bp) genes and morphological data ( 56 characters) from 13 species, thereafter subjecting the combined data to MP analysis, and suggested that the saccopharyngiforms are deeply nested within the anguilliforms. Obermiller and Pfeiler (2003) also analyzed mtDNA sequences (754 bp) in segments of the $12 S$ and $16 \mathrm{~S}$ rRNA genes from 45 species including 33 elopomorphs, nine osteoglossomorphs, and three clupeomorphs and did not support the monophyly of Elopomorpha. Inoue et al. (2004) investigated Elopomorpha monophyly and interrelationships at the ordinal level using complete mitochondrial genomic data from 33 
species represent the major teleostean and elopomorph lineages. Mitogenomic data strongly supported the order Elopiformes occupied the most basal position in the elopomorph phylogeny, with the Albuliformes and a clade comprising the Anguilliformes and the Saccopharyngiformes forming a sister group.

Mitochondrial DNA provides a potential tool for studying population and phylogenetic analysis and the different genes of mitochondrial genome are used for phylogeny analysis at different levels of taxa, family, species and individual's level. Hence, an attempt has been made to report the phylogenetic analysis based on the updated nucleotide sequence data from GenBank for the four regions of the mitochondrial genome (Cytb, CO1, 16S rRNA and $12 \mathrm{~S} \mathrm{rRNA}$ ) to assess the pattern of species relationship and also to examine the rates and types of nucleotide substitutions among the Tenpounder fish species.

\section{Materials and methods}

\section{Sample collection}

Forty specimens of Elops machnata were collected from Vellar estuary (Lat $11^{\circ} 29^{\prime} \mathrm{N}$; Lon $79^{\circ} 46^{\prime} \mathrm{E}$ ) southeast coast of India. Immediately after the collection, the specimens were kept in the icebox and the fishes were identified up to the species level using the FAO fish identification sheets (Thomson, 1984). The voucher specimens are maintained in Marine Biotechnology Laboratory, CAS in Marine Biology, Annamalai University. The fin-clips were preserved in $95 \%$ ethanol and stored at $4^{\circ} \mathrm{C}$ until used.

\section{DNA isolation}

The DNA was isolated by standard Proteinase-K/Phenol-Chloroform-ethanol method (Sambrook et al., 1989) and the concentration of isolated DNA was estimated using a UV spectrophotometer. The DNA was diluted in TAE buffer to a final concentration of $100 \mathrm{ng} \mu \mathrm{L}$.

\section{Gene amplification and sequencing}

The CO1 gene was amplified in a $50 \mu \mathrm{L}$ volume with 5 $\mu \mathrm{L}$ of $10 X$ Taq polymerase buffer, $2 \mu \mathrm{L}$ of $\mathrm{MgCl} 2(50 \mathrm{mM})$, $0.25 \mu \mathrm{L}$ of each dNTP $(0.05 \mathrm{mM}), 0.5 \mu \mathrm{L}$ of each primer $(0.01 \mathrm{mM}), 0.6 \mathrm{U}$ of Taq polymerase and $5 \mu \mathrm{L}$ of genomic DNA. The primers used for the amplification of the CO1 gene were FishF1-5' TCAACCAACCACAAAGACATTGGCAC 3' and FishR1-5' TAGACTTC TGGGTGGCCAAAGAATCA 3' (Ward et al., 2005). The thermal regime consisted of an initial step of $2 \mathrm{~min}$ at $95^{\circ} \mathrm{C}$ followed by 35 cycles of $40 \mathrm{~s}$ at $94^{\circ} \mathrm{C}, 45 \mathrm{~s}$ at $54^{\circ} \mathrm{C}$ and $1 \mathrm{~min}$ at $72^{\circ} \mathrm{C}$ followed in turn by final extension of $10 \mathrm{~min}$ at $72^{\circ} \mathrm{C}$.The PCR products were visualized on $1.5 \%$ agarose gels, and the most intense products were selected for sequencing. The cleaned up PCR product was sequenced by a commercial sequencing facility (Ramachandra Innovis, Chennai, India).

\section{Sequence analysis}

The CO1 gene partial sequences of Elops machnata were unambiguously edited using BioEdit sequence editor, aligned using CLUSTAL-W and checked manually. Haplotype definitions have been submitted to the NCBI GenBank (Acc. No. KF006255, KF006256, KF006257). To give more support to the present data, CO1, Cytb, 16S rRNA and 12S rRNA sequences of other available species were retrieved from GenBank and the details are given in Tab. 1. Nucleotide diversity, genetic variation, nucleotide composition and pairwise evolutionary distance among haplotypes were determined by Kimura 2-Parameter method (Kimura, 1980) using the software program MEGA 3.1 (Kumar et al., 2004). The neighbour-joining (NJ) trees for CO1, Cytb, 16S rRNA and 12S rRNA were constructed and to verify the robustness of the internal nodes of these trees, bootstrap analysis was carried out using 1000 pseudoreplications.

\section{Results and discussion}

A total of 58 sequences were from five Elops species were included and analysed in this study. Simplicity and un-ambiguity were observed among the sequences and no introns, deletions or stop codons were observed any of the $\mathrm{CO} 1$ and $\mathrm{Cytb}$ sequences. The $\mathrm{CO} 1$ sequence analysis revealed that the average nucleotide frequency was $\mathrm{A}$ $=24.16 \pm 0.78 \%, \mathrm{~T}=26.74 \pm 0.17 \%, \mathrm{G}=18.96 \pm 0.60$, $\mathrm{C}=30.14 \pm 1.72$ (Fig. 1). The interspecies transition and transversion was 86.23 and 13.78 respectively (Fig. 2). Tajima's statistics for E. machnata and E. hawaiensis were not significantly $(p<0.01)$ different among individuals. Kimura 2 Parameter (K2P) genetic distance in four Elops species is given in Tab. 2 (below diagonal). The K2P genetic distance was high $(0.023)$ between $E$. hawaiensis and $E$. affinis. Very low K2P distance (0.003) was exhibited between $E$. hawaiensis and E. machnata. The Cytb sequence analysis among the four species showed that the average nucleotide frequency was $\mathrm{A}=25.19 \pm 0.65 \%, \mathrm{~T}=26.54$ $\pm 0.12 \%, G=18.24 \pm 0.53, C=30.03 \pm 0.90$ (Fig. 1). The interspecies transition and transversion was 57.01 and 42.99 respectively and the $\mathrm{R}$ value was 1.28 (Fig. 2) based on the Cytb data. Tajima's statistics for Cytb sequence in E. smithi was not significantly $(p<0.01)$ different among individuals (Tab. 4). The K2P genetic distance based on the Cytb data among the Elops species is given in Tab. 3. The K2P genetic distance was high (1.231) between $E$. saurus and E. affinis and the distance was low (0.010) between E. hawaiensis and E. smithi.

The $16 \mathrm{~S}$ rRNA gene sequence analysis showed the average nucleotide frequency was $\mathrm{A}=31.63 \pm 0.82 \%, \mathrm{~T}=$ $13.99 \pm 0.42 \%, G=23.39 \pm 0.83, C=30.99 \pm 1.20$ (Fig. 1). The interspecies transition and transversion was 52.96 and 37.04 respectively and the $\mathrm{R}$ value was 1.70 (Fig. 2). The K2P genetic distance based on 16S rRNA gene data of Elops species is given in Tab. 4. The high (0.048) K2P 
284

Tab. 1. Elops species and their mitochondrial genes with accession number and reference

\begin{tabular}{|c|c|c|c|c|c|}
\hline \multirow{2}{*}{ Sl. No } & \multirow{2}{*}{ Species } & \multicolumn{4}{|c|}{ Accession Number } \\
\hline & & $\mathrm{CO} 1$ & Cyt b & 12S rRNA & 16S rRNA \\
\hline 1. & Elops machnata & JF493412a & - & AF417340' & - \\
\hline 2. & Elops machnata & JF493410 & - & - & - \\
\hline 3. & Elops machnata & $\mathrm{JF} 493413^{\mathrm{a}}$ & - & - & - \\
\hline 4. & Elops machnata & JF493411 $1^{\mathrm{a}}$ & & - & - \\
\hline 5. & Elops machnata & KF006255 & - & - & - \\
\hline 6. & Elops machnata & KF006256 & - & - & - \\
\hline 7. & Elops machnata & KF006257 ${ }^{b}$ & - & - & - \\
\hline 8. & Elops saurus & GU702393 & $\mathrm{AP} 004807^{\mathrm{f}}$ & $\mathrm{AP} 004807^{\mathrm{f}}$ & $\mathrm{KC} 146866^{\mathrm{a}}$ \\
\hline 9. & Elopssaurus & GU702337 & NC_005803 $3^{\mathrm{f}}$ & - & $\mathrm{KC} 146864^{\mathrm{a}}$ \\
\hline 10. & Elopssaurus & GU702338d & - & - & $\mathrm{KC} 146867^{\mathrm{a}}$ \\
\hline 11. & Elopssaurus & JQ365344 & - & - & $\mathrm{KC} 146865^{\mathrm{a}}$ \\
\hline 12. & Elopssaurus & JN025309 & - & - & $\mathrm{KC} 146863^{\mathrm{a}}$ \\
\hline 13. & Elopssaurus & GU224782a & - & - & AF $455766^{\circ}$ \\
\hline 14. & Elopssaurus & GU224783a & - & - & - \\
\hline 15. & Elopssaurus & GU225201 & - & - & - \\
\hline 16. & Elopssaurus & GU225600 & - & - & - \\
\hline 17. & Elopssaurus & GU225200" & - & - & - \\
\hline 18. & Elops hawaiensis & $\mathrm{EF} 609347^{\mathrm{h}}$ & HQ616667 & - & X99175' \\
\hline 19. & Elops hawaiensis & $\mathrm{EF} 607367^{\mathrm{i}}$ & HQ157200k & - & - \\
\hline 20. & Elops hawaiensis & $\mathrm{EF} 607365^{\mathrm{i}}$ & HQ616666k & - & - \\
\hline 21. & Elops hawaiensis & EF607366 & HQ157201k & - & - \\
\hline 22. & Elops hawaiensis & EF607364i & $\mathrm{AB} 051070^{\mathrm{f}}$ & - & - \\
\hline 23. & Elops hawaiensis & EU595109a & NC_005798 & NC_005798f & - \\
\hline 24. & Elops hawaiensis & JF952722 & - & X99176 & - \\
\hline 25. & Elops affinis & GU440309 & DQ082913ª & AF $454710^{g}$ & AF $455765^{\mathrm{g}}$ \\
\hline 26. & Elops affinis & EU403078 a & - & - & AY836585 \\
\hline 27. & Elops smithi & - & GQ183893 & - & - \\
\hline 28. & Elops smithi & - & GQ183889m & - & - \\
\hline 29. & Elops smithi & - & GQ183887m & - & - \\
\hline 30. & Elops smithi & - & GQ183885 ${ }^{\mathrm{m}}$ & - & - \\
\hline 31. & Elops smithi & - & GQ183883 & - & - \\
\hline 32. & Elopssmithi & - & GQ183890m & - & - \\
\hline 33. & Elops smithi & - & GQ183888m & - & - \\
\hline 34. & Elops smithi & - & GQ183886m & - & - \\
\hline 35. & Elops smithi & - & GQ183884 ${ }^{\mathrm{m}}$ & - & - \\
\hline
\end{tabular}

${ }^{\mathrm{a} U n p u b l i s h e d ; ~}{ }^{\mathrm{b}}$ Present study; 'Wang et al.,2003; ${ }^{\mathrm{d}}$ Rosso et al., 2012; ${ }^{\mathrm{e} A p r i l}$ et al., 2011; ${ }^{\mathrm{f}}$ Inoue et al., 2004; ' $\mathrm{Obermiller}$ and Pfeiler, 2003 ; ${ }^{\mathrm{h}}$ Ward and Holmes, 2007 ;

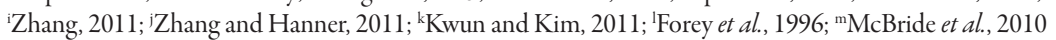

genetic distance was observed between $E$. saurus and $E$. hawaiensis and low (0.024) among E. saurus and E. affinis. The $12 \mathrm{~S}$ rRNA gene sequence analysis result showed the average nucleotide frequency was $\mathrm{A}=28.81 \pm 0.43 \%$, $\mathrm{T}$ $=21.19 \pm 0.31 \%, G=26.44 \pm 0.32, C=23.56 \pm 0.70$ (Fig. 1). The transition and transversion among the species was 37.85 and 62.15 respectively and the $R$ value was 0.68 (Fig. 2). The K2P genetic distance based on 12S rRNA gene sequence data of the fish species is given in Tab. 2 (above diagonal). The K2P genetic distance was high (0.035) between E. saurus and E. affinis and low (0.004) genetic distance was observed between $E$. hawaiensis and E. machnata.
The neighbour-joining method was actually employed in this study to get a solid phylogenetic information by the dendrogram. All the 58 sequences of the tenpounder fishes were subjected in the phylogenetic analysis. The neighbour joining trees by K2P model for the four mitochondrial genes were created to provide a graphical representation of the patterning of divergence of five Elops species. The neighbour joining phylogenetic tree based on $\mathrm{CO} 1$ gene sequences is given in Fig. 3. As per the NJ tree, two distinct clades as two sub-trees within the same genus were recognized with high bootstrap value. Among the two sub-trees, one has an independent assemblage of E. hawaiensis and E. machnata with $98 \%$ bootstrap value. Another clade representing the other two species such as 


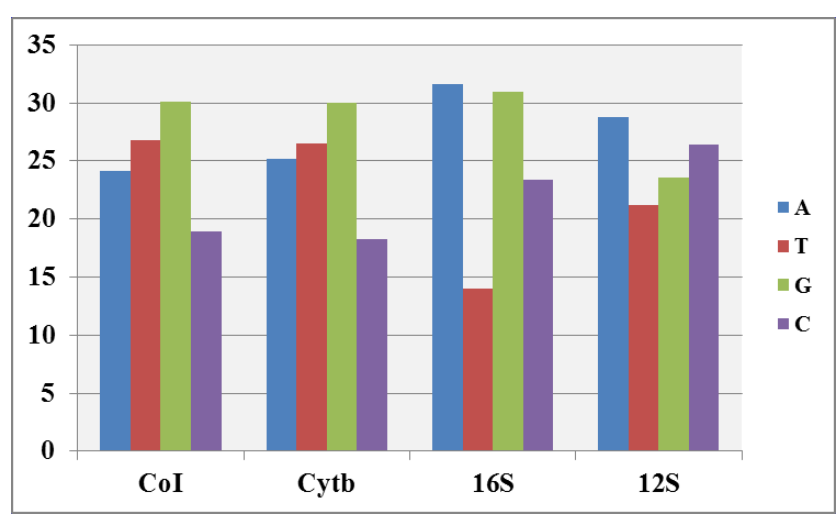

Fig. 1. Percentage of nucleotide composition in four mitochondrial genes of Elops species

E. saurus and E. affinis. Fig. 4 shows the neighbour joining phylogenetic tree based on Cytb gene sequences. In this tree, two distinct clusters are raised with high bootstrap value. Among the two clusters, one large has an assemblage of $E$. hawaiensis, E. saurus and E. smithi with $54 \%$ bootstrap value. Another clade representing the other one species, E. affinis.

The neighbour joining phylogenetic tree based on $16 \mathrm{~S}$ rRNA gene sequences is given in Fig. 5. As per this tree, three distinct clades as sub-trees within the Elops genus were recognized with high bootstrap value. Among the three sub-trees, one has the cluster of E. saurus with 84\%

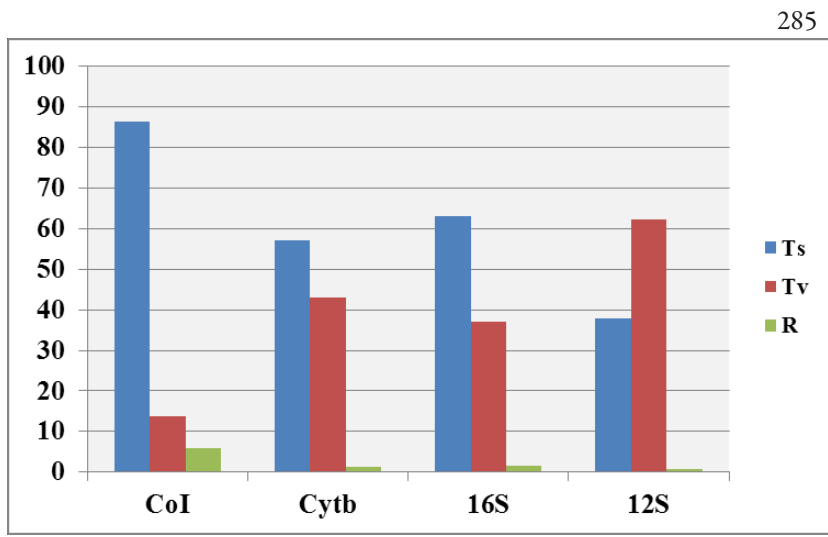

Fig. 2. The nucleotide substitution patterns of four mitochondrial genes based on the Kimura (1980) 2-parameter model (Ts-Transition; Tv-Transversion; R-estimated Transition/ Transversion bias)

bootstrap value. The second clad representing $E$. affinis with bootstrap value of $59 \%$ and the third branch was $E$. hawaiensis. Fig. 6 shows the neighbour joining tree based on $12 S$ rRNA gene sequences. In this tree, one large cluster has an assemblage of $E$. hawaiensis, E. saurus and $E$. machnata. Another small clade representing the deviated species, E. affinis as like Cytb NJ tree.

Species identification and phylogenetic relationship based on traditional methods and molecular methods are mostly concordant (Ward et al., 2005). The efficiency of species identification by molecular methods is judged by

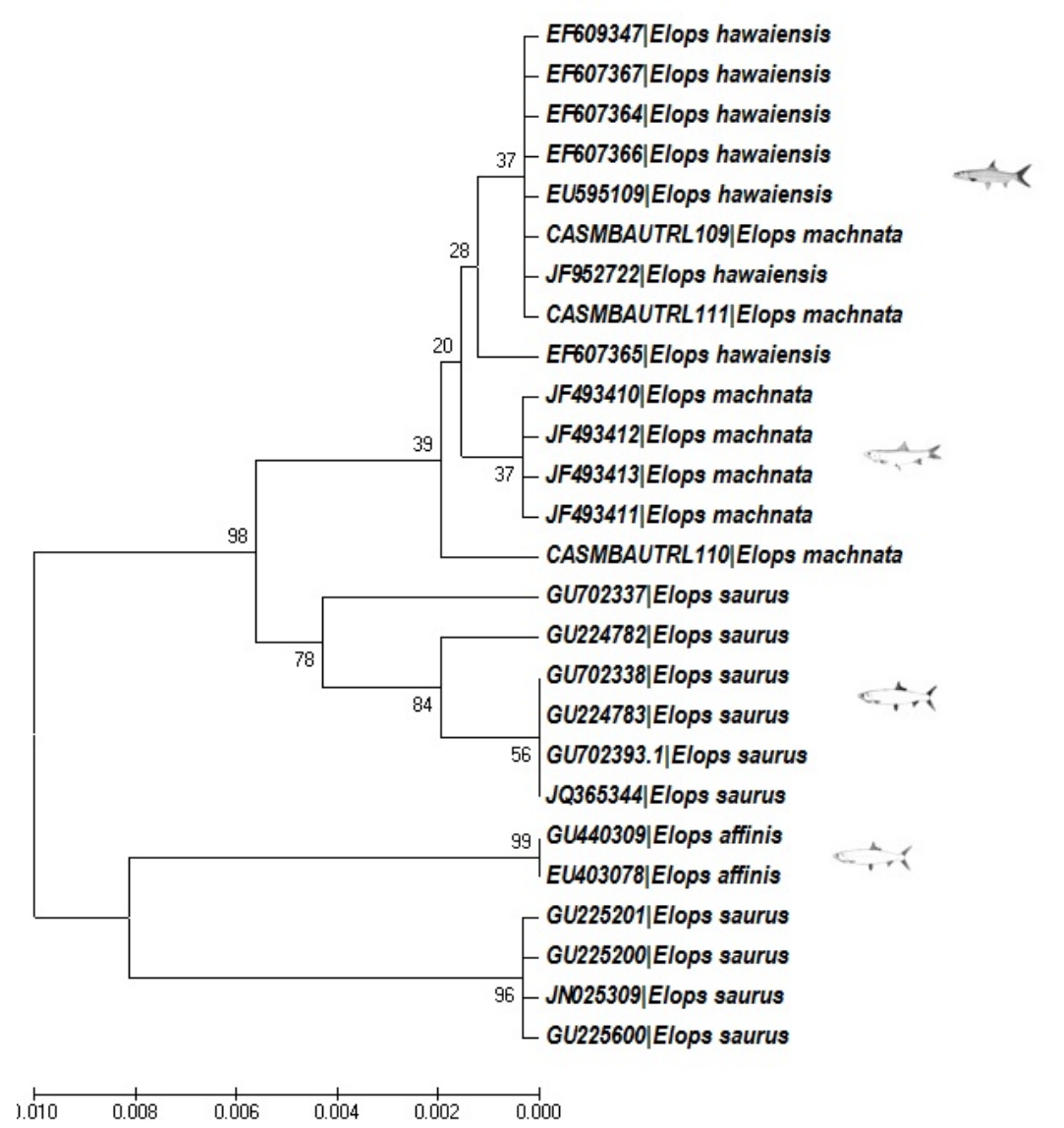

Fig. 3. Neighbour joining tree of Elops species based on CO1 gene sequences 
Tab. 2. K2P genetic distance between Elops species based on CO1 gene sequences (below diagonal), based on $12 \mathrm{~S}$ rRNA gene sequences (above diagonal)

\begin{tabular}{ccccc}
\hline Species & Elops machnata & Elops saurus & Elops hawaiensis & Elops affinis \\
\hline Elops machnata & $* * * * *$ & 0.009 & 0.013 & 0.026 \\
Elops saurus & 0.014 & ${ }^{* * * *}$ & ${ }^{* * * * *}$ & 0.035 \\
Elops hawaiensis & 0.003 & 0.014 & 0.023 & 0.030 \\
Elops affinis & 0.020 & 0.021 & ${ }^{* * * *}$ \\
\hline
\end{tabular}

Tab. 3. K2P genetic distance between Elops species based on Cytb gene sequences

\begin{tabular}{ccccc}
\hline Species & Elops smithi & Elops saurus & Elops hawaiensis & Elops affinis \\
\hline Elops smithi & ${ }^{* * * * *}$ & & & \\
Elops saurus & 0.013 & ${ }^{* * * * *}$ & ${ }^{* * * * *}$ & \\
Elops hawaiensis & 0.010 & 0.013 & 1.207 & $* * * *$ \\
Elops affinis & 1.210 & 1.231 & $* 2$ \\
\hline
\end{tabular}

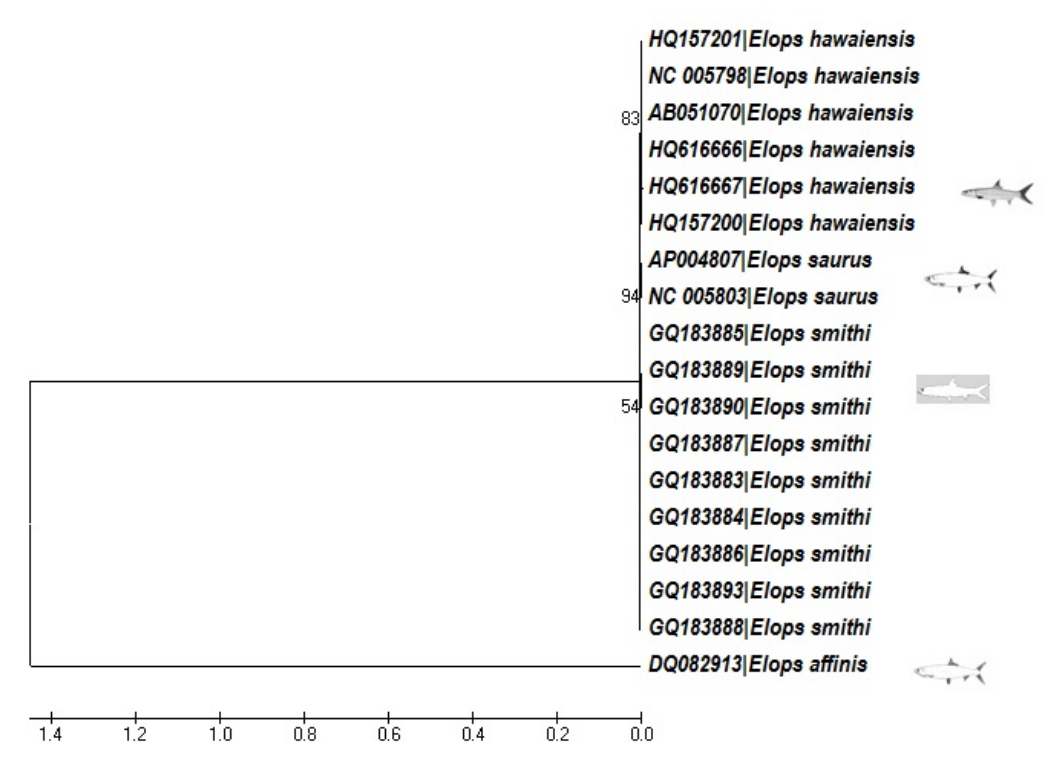

Fig. 4. Neighbour joining tree of Elops species based on Cytb gene sequences

the levels of intraspecific homogeneity and interspecific heterogenenity displayed by the intended method (Hallden et al., 1994; Lievens et al., 2001). Mitochondrial CO1 gene, as an attractive "species barcode", its high efficiency in species identification has been reported in Australia marine fishes (Ward et al., 2005), Canadian freshwater fishes (Hubert et al., 2008), ornamental fishes in the market of North America (Steinke et al., 2009b) and marine fishes of Japan (Zhang and Hanner, 2011). Due to the high efficiency in species identification, some ichthyologists advocate the inclusion of a DNA barcode in the formal description of species (Victor, 2007; Astarloa et al., 2008). Somehow, it deserves attention to recent speciation, introgressive hybridization, and taxonomic splitting, which Tab. 4. K2P genetic distance between Elops species based on $16 \mathrm{~S}$ rRNA gene sequences

\begin{tabular}{cccc}
\hline Species & Elops saurus & Elops hawaiensis & Elops affinis \\
\hline Elops saurus & $* * * *$ & & \\
Elops hawaiensis & 0.048 & ${ }^{* * * * *}$ & \\
Elops affinis & 0.024 & 0.038 & ${ }^{* * * * *}$ \\
\hline
\end{tabular}

may cause the inability of CO1 barcodes. In such cases, a secondary independent molecular marker is required to solidify or confirm identification if applicable (Smith et al., 2007). In this study five Elops species were found genetically distinct from each other based on four mtDNA gene sequences which demonstrates simplicity and unambiguity. Morphologically very similar species like $E$. affinis and $E$. saurus form sister clade by all the four gene based NJ trees. Whereas, E. machnata and E. hawaiensis form an independent sister clade in NJ tree of CO1 gene. Because of the data deficient in GenBank we could not clearly resolve $E$. smith $i$ from all other species. The observed genetic divergence from $\mathrm{CO} 1$ gene is sufficient to differentiate individuals of different Elops species. In this study the level of intra-species variation was low which may be due to low number of haplotype identified in the sample with limited numbers collected for this study. Similarly, Lakra et al. (2011) reported very low intra-specific genetic divergence for scombroid fishes and Ward et al. (2005) showed in many marine teleost species. Peris et al. (2009) also reported very low interspecies genetic distance for Indian 


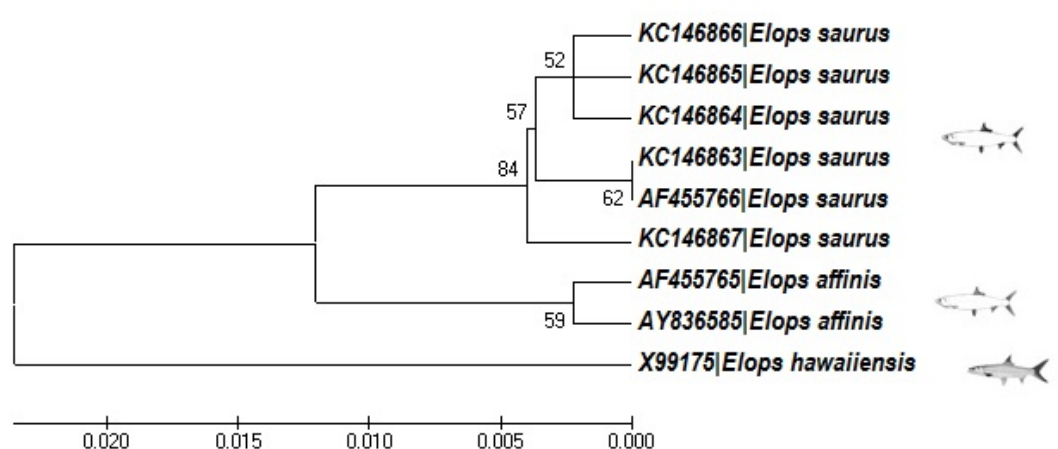

Fig. 5. Neighbour joining tree of Elops species based on $16 \mathrm{~S}$ rRNA gene sequences

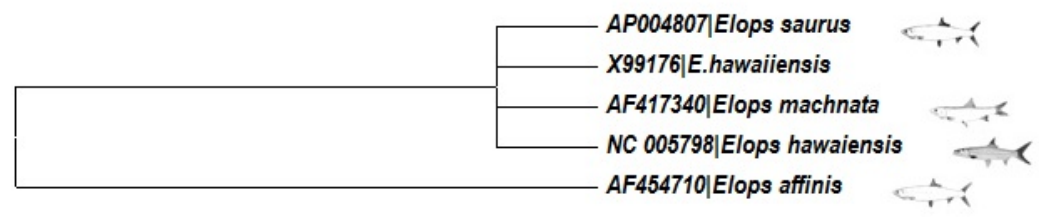

\begin{tabular}{llll}
\hline & 1 & 1 & \\
\hline 0.015 & 0.010 & 0.005 & 0.000
\end{tabular}

Fig. 6. Neighbour joining tree of Elops species based on $12 \mathrm{~S}$ rRNA gene sequences

Tab. 5. Tajima's Neutrality Test for CO1 and Cytb genes in Elops species

\begin{tabular}{ccccccccc}
\hline Gene & Species & $\mathrm{M}$ & $\mathrm{S}$ & $\mathrm{Ps}$ & $\Theta$ & $\pi$ & $\mathrm{D}$ \\
\hline \multirow{4}{*}{ CO1 } & Elops machnata & 7 & 4 & 0.006885 & 0.002810 & 0.002295 & -0.876418 \\
& Elops saurus & 10 & 16 & 0.027586 & 0.009751 & 0.011916 & 1.027479 \\
& Elops hawaiensis & 7 & 3 & 0.005803 & 0.002368 & 0.001658 & -1.358415 \\
& Elops affinis & 4 & 0 & 0.000000 & $0.00000 \mathrm{E}+000$ & 0.000000 & $\mathrm{n} / \mathrm{c}$ \\
\hline \multirow{4}{*}{ Cytb } & Elops smithi & 9 & 13 & 0.027660 & 0.010177 & 0.007092 & -1.446159 \\
& Elops saurus & 3 & 0 & 0.000000 & $0.00000 \mathrm{E}+000$ & 0.000000 & $\mathrm{n} / \mathrm{c}$ \\
& Elops hawaiensis & 5 & 577 & 0.973019 & 0.426140 & 0.634963 & 3.190463 \\
& Elops affinis & 3 & 0 & 0.000000 & $0.00000 \mathrm{E}+000$ & 0.000000 & $\mathrm{n} / \mathrm{c}$ \\
\hline
\end{tabular}

$\mathrm{M}=$ number of sequences, $\mathrm{S}=$ Number of segregating sites, $\mathrm{ps}=\mathrm{S} / \mathrm{m}, \Theta=\mathrm{ps} / \mathrm{al}, \pi=$ nucleotide diversity, and $\mathrm{D}=$ Tajima test statistic

carangid fishes. For many marine fishes, there is a lack of the mean GC content in CO1 was $49.10 \%$ and in Cytb it phylogeographic structure among populations (Palumbi, 1994; Hellberg et al., 2002). Zhang (2011) reported that, individuals from long distance localities, some intraspecific genetic variations reduced to zero within families Carangidae, Sciaenidae, and Mullidae. However, some pairwise K2P distances exceeded $1.00 \%$ within the coastal species such as Acentrogobius caninus, Scomber japonicus, Terapon jarbua, Upeneus sulphureus, Elops hawaiensis, Gymnothorax pseudothyrsoideus, and Dendrophysa russelii. Based on the CO1 data, the present study also confirmed that the interspecies K2P genetic variation is more than $1.00 \%$. It implied that biological mechanisms were responsible for the fluctuation of intraspecific genetic divergences in marine fishes.

Ward et al. (2005) reported an overall higher GC content in fishes based on complete $\mathrm{MtDNA}$ genome ranging from $38.4-43.2 \%$ and in $\mathrm{CO} 1$ alone it was $42.2-47.1 \%$, which reflects the $3^{\text {rd }}$ base variation. Peris et al. (2009) also reported considerable variation was exhibited in carangids in the 3rd base position. Ravitchandirane et al. (2012) showed the mean GC content was 36.8 - $42.6 \%$ among the nine Nemipterus species. In this study it has been observed

was $48.27 \%$ among the five Elops species.

The genetic distance between Elops sp. and E. saurus, which occur sympatrically in Florida (Smith, 1989), was 0.021 , similar to that found between the allopatric $E$. saurus and E. hawaiensis (0.024) (Obermiller et al., 2003) which inhabit different ocean basins. The present study revealed that the K2P genetic distance between the allopatric E. saurus and E. hawaiensis was 0.014 based on CO1 data and it was 0.013 based on Cyt b and $12 \mathrm{~S}$ rRNA gene sequence data respectively.

It is unfeasible to build the phylogeny of Elopiforme fishes only based on mitochondrial DNA fragments alone. The disadvantage of $16 \mathrm{~S} \mathrm{rDNA}$ sequences is the lack of discrimination power among closely related species. However, this problem can be overcome by analysing in parallel other gene markers. Polyphyly/paraphyly in the NJ tree probably results from "bad taxonomy" when named species fail to identify the genetic limits of separate evolutionary entities, particularly for perplexing taxa involving cryptic species (Nice and Shapiro, 2001). All the four mitochondrial marker genes used in this study showed different type of cluster and we could not confirm the re- 
288

lationship between the Elops species. This is due to the independent mutation rate of each mtDNA genes. Different nucleotide positions and genes within mtDNA are known to evolve at heterogeneous rates within a lineage (Brown et al., 1982; Gillespie, 1986; Moritz et al., 1987), and particular mtDNA genes (such as cytochrome oxidase) also show rate differences as high as fivefold across lineages (Brown and Simpson, 1982; Crozier et al., 1989). As per Zhang (2011), if we cannot set a threshold of the genetic variation in species delimitation, we find ourselves sunk in the dilemma facing new or cryptic species. On the one hand, the morphological taxonomy cannot give a definite identification. On the other hand, we cannot claim that it may be a new species based on molecular analysis without the species delimitation (Zhang, 2011). An assumed threshold is helpful to expedite discovery of new species and biodiversity, especially in dealing with little-studied biota, although a single, uniform threshold for species delimitation seems arbitrary because the rates of molecular evolution vary widely within and among lineages (Zuckerkandl and Pauling, 1965; Will and Rubinoff, 2004; DeSalle et al., 2005).

\section{Conclusions}

The study has successfully assessed the utility of the four genes (Cytb, CO1, 16S and 12S rRNA) of mitochondrial genome to estimate the relationships among five Elops species such as Elops saurus, E. affinis, E. smithi, E. machnata and $E$. hawaiensis. The four mitochondrial marker genes used in this study showed different type of cluster and we could not confirm the relationship between the five Elops species. This is due to the independent mutation rate of each mtDNA genes. However, this problem can be overcome by analysing in parallel by other gene markers also. Further studies involving all the Elopiformes in the world and also by increasing the sample size in future studies will clarify the issue.

\section{Acknowledgements}

The authors would like to thank The Director, CAS in Marine Biology and The Authorities of Annamalai University for encouragement and facilities.

\section{References}

April J, Mayden RL, Hanner RH, Bernatchez L (2011). Genetic calibration of species diversity among North America's freshwater fishes. Proc Natl Acad Sci USA 108(26):1060210607.

Astarloa JMD, Mabragana E, Hanner R (2008). Morphological and molecular evidence for a new species of longnose skate (Rajiformes: Rajidae: Dipturus) from Argentinean waters based on DNA barcoding. Zootaxa 1921:35-46.

Brown WM, Prager EM, Wang A, Wilson AC (1982). Mitochondrial DNA sequences of primates: tempo and mode of evolution. J Mol Evol 18:225-239.

Brown GG, Simpson MV (1982). Novel features of animal mtDNA evolution as shown by sequences of two rat cytochrome oxidase subunit II genes. Proc Natl Acad Sci USA 79:3246-3250.

Crozier RH, Crozier YC, Mackinlay AG (1989). The CO-I and CO-II region of honeybee mitochondrial DNA: evidence for variation in insect mitochondrial evolutionary rates. Mol Biol Evol 6:399-411.

DeSalle R, Egan MG, Siddall M (2005). The unholy trinity: taxonomy, species delimitation and DNA barcoding. Philos Trans R Soc Lond B Biol Sci 360(1462):1905-1916.

Eschmeyer WN, Fong JD (2013). Species by Family/subfamily in the Catalog of Fishes. Available from http:// research. calacademy.org/research/ichthyology/catalog/SpeciesByFamily. asp (accessed 09 May 2013).

Filleul A, Lavoue S (2001). Basal teleosts and the question of elopomorph monophyly. Morphological and molecular approaches. C R Acad Sci Paris Life Sci: 324: 393-399.

Forey P, Littlewood DTJ, Ritchie P, Meyer A (1996). Interrelationships of elopomorph fishes, 175-191 p. In: Stiassny MLJ, Parenti LR, Johnson DG (Eds.). Interrelationships of Fishes, Academic Press, San Diego.

Gillespie JH (1986). Variability of evolutionary rates of DNA. Genetics 113:1077-1091.

Hallden C, Nilsson NO, Rading IN, Sall T (1994). Evaluation of RFLP and RAPD markers in a comparison of Brassica napus breeding lines. Theor Appl Genet 88:123-128.

Hellberg ME, Burton RS, Neigel JE, Palumbi SR (2002). Genetic assessment of connectivity among marine populations. Bull Mar Sci 70(1):273-290.

Hubert N, Hanner R, Holm E, Mandrak NE, Taylor E, Burridge M, Watkinson D, Dumont P, Curry A, Bentzen P, Zhang J, April J, Bernatchez L (2008). Identifying Canadian freshwater fishes through DNA barcodes. PLos ONE 3(6):e2490.

Inoue JG, Miya M, Tsukamoto K, Nishida M (2004). Mitogenomic evidence for the monophyly of elopomorph fishes (Teleostei) and the evolutionary origin of the leptocephalus larva. Mol Phylogenet Evol 32(1):274-286.

Kimura M (1980). A simple method of estimating evolutionary rate of base substitutions through comparative studies of nucleotide sequences. J Molec Evol 16:111-120.

Kumar S, Tamura K, Nei M (2004). MEGA3: Integrated software for molecular evolutionary genetics analysis and sequence alignment. Brief Bioinfo 5:150-163.

Kwun HJ, Kim JK (2011). Redescription of the Hawaiian ladyfish, Elops hawaiensis from Korea. Korean J Ichthyol 23(1):80-84.

Lakra WS, Verma MS, Goswami M, Lal KK, Mohindra V, Punia P, Gopalakrishnan A, Singh K V, Ward RD, Hebert $P$ (2011). DNA barcoding Indian marine fishes. Mol Ecol Res 11: 60-71.

Lievens S, Goormachtig S, Holsters M (2001). A critical evalua- 
tion of differential display as a tool to identify genes involved in legume nodulation: looking back and looking forward. Nucl Acids Res 29: 3459-3468.

McBride RS, Rocha CR, Ruiz-Carus R, Bowen BW (2010). A new species of ladyfish, of the genus Elops (Elopiformes: Elopidae), from the western Atlantic Ocean. Zootaxa 2346:29-41.

Moritz C, Dowling TE, Brown WM (1987). Evolution of animal mitochondrial DNA: relevance for population biology and systematics. Annu Rev Ecol Syst 18:269-292.

Nelson JS (2006). Fishes of the World (4th Edition). John Wiley \& Sons, New York, 601 p.

Nice CC, Shapiro AM (2001). Patterns of morphological, biochemical, and molecular evolution in the Oeneis chryxus complex (Lepidoptera: Satyridae): a test of historical biogeographical hypotheses. Mole Phy Evol 20(1):111-123.

Obermiller LE, Pfeiler E (2003). Phylogenetic relationships of elopomorph fishes inferred from mitochondrial ribosomal DNA sequences. Mol Phy Evol 26(2):202-214.

Palumbi SR (1994). Genetic divergence, reproductive isolation and marine speciation. Ann Rev Ecol Syst 25:547-572.

Peris M, Chandra Sekhar Reddy A, Rao LM, Khedkar GD, Ravinder K, Nasruddin K (2009). CO1 (Cytochrome oxidase-1) sequence based studies of Carangid fishes from Kakinada coast, India. Mol Biol Rep 36:1733-1740.

Ravitchandirane V, Geetha V, Ramya V, Janifer B, Thangaraj M, Subburaj J, Ramanadevi V, Ganesan T (2012). Molecular identification and phylogenetic relationships of Threadfin Breams (Family: Nemipteridae) using mtDNA marker. Not Sci Biol 4(2):13-18.

Rosso JJ, Mabragana E, Gonzalez Castro M, Diaz de Astarloa JM (2012). DNA barcoding Neotropical fishes: recent advances from the Pampa Plain, Argentina. Mol Ecol Resour 12(6):999-1011.

Sambrook J, Fritsch EF, Maniatis T (1989). Molecular cloning: a laboratory manual, 2nd Ed. Cold Spring Harbor Laboratory Press, Cold Spring Harbor, NY.

Smith DG (1989). Order Elopiformes; Families Elopidae, Megalopidae, and Albulidae: Leptocephali. Memoir SearsFoundation for Marine Research. Number I. Fishes of the Western North Atlantic. Sears Foundation for Marine Research, Yale University, New Haven 9(2):961-972.
Smith MA, Wood DM, Janzen DH, Hallwachs W, Hebert PI (2007). DNA barcodes affirm that 16 species of apparently generalist tropical parasitoid flies (Diptera, Tachinidae) are not all generalists. Proc Natl Acad Sci USA 104:49674972.

Steinke D, Zemlak TS, Hebert PDN (2009b). Barcoding Nemo: DNA-Based identifications for the ornamental fish Trade. PLos ONE 4:e6300.

Thomson JM (1984). In FAO species identification sheets for fishery purpose, Western Indian Ocean fishing area. Fisher, W and Bianchi G (Eds.), FAO, Rome, Vol.3.

Victor BC (2007). Coryphopterus kuna, a new goby (Perciformes: Gobiidae: Gobiinae) from the western Caribbean, with the identification of the late larval stage and an estimate of the pelagic larval duration. Zootaxa 1526:51-61.

Wang CH, Kuo CH, Mok HK, Lee SC (2003). Molecular phylogeny of elopomorph fishes inferred from mitochondrial $12 S$ ribosomal RNA sequences. Zool Scr 32(3):231-241.

Ward RD, Holmes BH (2007). An analysis of nucleotide and amino acid variability in the barcode region of cytochrome $\mathrm{c}$ oxidase 1 (cox1) in fishes. Mol Ecol Notes 7(6):899-907.

Ward RD, Zemlac TC, Innes BH, Last PR, Hebert PDN (2005). DNA barcoding Australia's fish species. Philos Transact Royal Soc B 360:1847-1857.

Will KW, Rubinoff D (2004). Myth of the molecule: DNA barcodes for species cannot replace morphology for identification and classification. Cladistics 20(1):47-55.

Zhang J (2011). Species identification of marine fishes in china with DNA barcoding. Evid Based Complement Alternat Med 2011(978253):1-10.

Zhang JB, Hanner R (2011). DNA barcoding is a useful tool for the identification of marine fishes from Japan. Biochem Syst Ecol 39(1):31-42.

Zuckerkandl E, Pauling L (1995). Evolutionary divergence and convergence in proteins, 97-166 p. In: Bryson V, Vogel HJ (Eds.). Evolving Genes and Proteins, Academic Press, New York, NY, USA. 